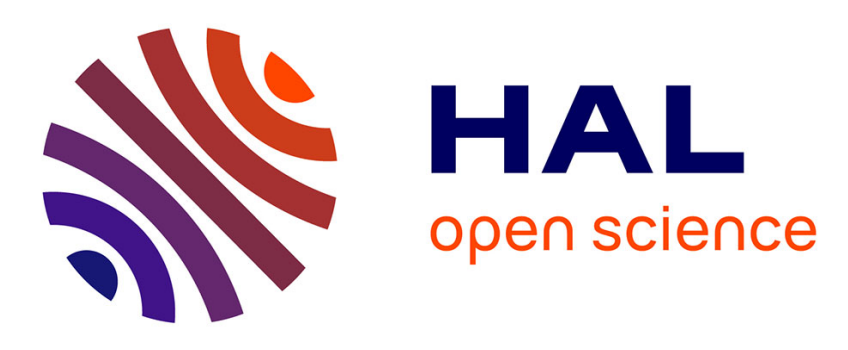

\title{
New unspiked K-Ar ages of quaternary sub-glacial and sub-aerial volcanic activity in Iceland
}

Hervé Guillou, Brigitte van Vliet-Lanoë, Agust Gudmundsson, Sébastien Nomade

\section{- To cite this version:}

Hervé Guillou, Brigitte van Vliet-Lanoë, Agust Gudmundsson, Sébastien Nomade. New unspiked $\mathrm{K}$-Ar ages of quaternary sub-glacial and sub-aerial volcanic activity in Iceland. Iceland in the central Northern Atlantic: hotspot, sea currents and climate change, May 2010, Plouzané, France. hal00482046

\section{HAL Id: hal-00482046 https: / hal.univ-brest.fr/hal-00482046}

Submitted on 7 May 2010

HAL is a multi-disciplinary open access archive for the deposit and dissemination of scientific research documents, whether they are published or not. The documents may come from teaching and research institutions in France or abroad, or from public or private research centers.
L'archive ouverte pluridisciplinaire HAL, est destinée au dépôt et à la diffusion de documents scientifiques de niveau recherche, publiés ou non, émanant des établissements d'enseignement et de recherche français ou étrangers, des laboratoires publics ou privés. 


\title{
NEW UNSPIKED K-AR AGES OF QUATERNARY SUB-GLACIAL AND SUB- AERIAL VOLCANIC ACTIVITY IN ICELAND
}

\author{
Hervé Guillou ${ }^{(1)}$, Brigitte Van Vliet-Lanoë ${ }^{(2)}$, Agust Guðmundsson ${ }^{(3)}$ and Sébastien Nomade ${ }^{(1)}$ \\ (1) : LSCE/IPSL, Laboratoire CEA-CNRS-UVSQ, Domaine du CNRS , Bât. 12, Avenue de la Terrasse, \\ 91198 Gif sur Yvette, France
}

(2) : UMR 6538 CNRS Domaines Océaniques,IUEM, Place N.Copernic, 29480 Plouzané, France

(3) : JFS ,Geological Services Raudagerdi 31, 108 Reykjavik, Iceland

\section{Introduction}

Application of volcanic proxies to paleoenvironmental studies in Iceland has generally lagged behind the improvements of undisputable geochronologies. This is particularly frustrating because a link between volcanism and deglaciation in Iceland is an appealing hypothesis and questions about the extent of the ice cap during Icelandic glaciations remain pending (Einarsson et al., 1988; Geirsdttir et al., 1997; Ingolfsson et al., 1997; Hoppe, 1982).

The postglacial eruptive history of Iceland after the last deglaciation is now well documented (Licciardi et al., 2007; Sinton et al., 2005, Saemundsson, 1991). One of its main characteristics is an increase in the volcanic eruption rate, which coincides with the end of the last ice age (11 ka BP; Slater et al., 1998; Maclennan et al., 2002; Sigvaldason et al., 1992; Hardarson et al., 1991; Jull et al., 1996). However, the pattern of volcanism for more evolved rocks, such as rhyolites, comprising 10$12 \%$ of outcrop on Iceland, is less well established. In fact, the opposite trend may be apparent, or at least sub-glacial rhyolite eruptions are frequent during interglacial periods (Flude et al., 2008).

This relationship between deglaciation and volcanism has been convincingly demonstrated in Iceland only for the last deglaciation (Maclennan et al., 2004; Sinton et al., 2005; Licciardi et al., 2007, McGarvie et al., 2006, McGarvie et al., 2007). Therefore, we consider that it is important to explore this relationship through older periods.

The purpose of this study is then to evaluate the potential of the unspiked K-Ar dating method in dating Quaternary Icelandic volcanics to contribute to this debate.

The unspiked K-Ar technique applied here is perfectly adapted to these purposes because it is an accurate and precise dating tool which has proven to be efficient and suitable to date young Quaternary lavas. To test the relevance of our approach, we collected and dated sub-aerial lavas contemporaneous with warm periods; hyaloclastites and lavas formed in sub-glacial environments.

\section{Geological setting of the dated samples}

Volcanism in Iceland, initiated about $12 \mathrm{Ma}$ ago and is still active, occurring during both glacial and interglacial periods. Two types of sub-glacial volcanic bodies are distinguished: Table Mountains also known as Móbergs or Tuyas and Hyaloclastite ridges.

Table mountain volcanoes which result from central vent eruptions are the sub-glacial equivalent of sub-aerial shield volcanoes (Werner et al., 1996). They are produced when volcanoes erupt beneath a pre-existing ice-sheet. Their shape is roughly circular with steep flanks and characterized by a flat top. At their base, their diameters vary from several hundred meters to a few kilometers. Their height usually ranges between 200 and 1000m. From the base to the top, they consist of a thick pile of pillow-lavas and hyaloclastites surrounded by volcanic breccias. This succession reflects a decrease in external pressure as the volcano grows higher toward the ice cap surface, during its evolution. When the magmatic activity was strong and sufficiently long-lasting, flat-lying sub-aerial lava flows capped these volcanoes. Thus, the height of these table mountains may be a good indicator of ice thickness at the time of their emplacement (Bourgeois et al., 1998; Werner et al., 1999; Smellie, 2000).

Hyaloclastite ridges can be as long as $40 \mathrm{~km}, 2-4 \mathrm{~km}$ wide and several hundred meters high. They are the sub-glacial equivalent of aerial eruptive fissures and they are aligned within the general tectonic trend. They are made up of fragmented pillow-lavas and hyaloclastites. It is generally accepted that the volumes of lava emitted during sub-glacial fissural eruptions are lower than those that produced the table mountain volcanoes (Guðmundsson, 1986). 


\section{Ecole Thématique - CNRS - Spring School \\ ICELAND IN THE CENTRAL NORTHERN ATLANTIC \\ IUEM Plouzané, FRANCE 11-14 Mai 2010}

During warmer periods, sub-aerial eruptions dominate. In comparison with sub-glacial eruptions which produced high topographic bodies of restricted lateral extent, sub-aerial eruptions tend to drape and smooth the topography. During these eruptions, very large lava flows flowing from eruptive fissures or shields can be generated. Volumes can occasionally exceed $20 \mathrm{~km}^{3}$ (Lakí lava flows field) and can be both of pahoehoe and aa types. The Gerduberg basalt columns are a spectacular example of sub-aerial volcanic activity.

Twenty-three samples were selected for this geochronological study. 12 samples are from Móbergs or hyaloclastite ridges and are considered to be emplaced in sub-glacial environments. The other 11 samples were collected from sub-aerial lava flows emplaced in an ice-free environment.

A

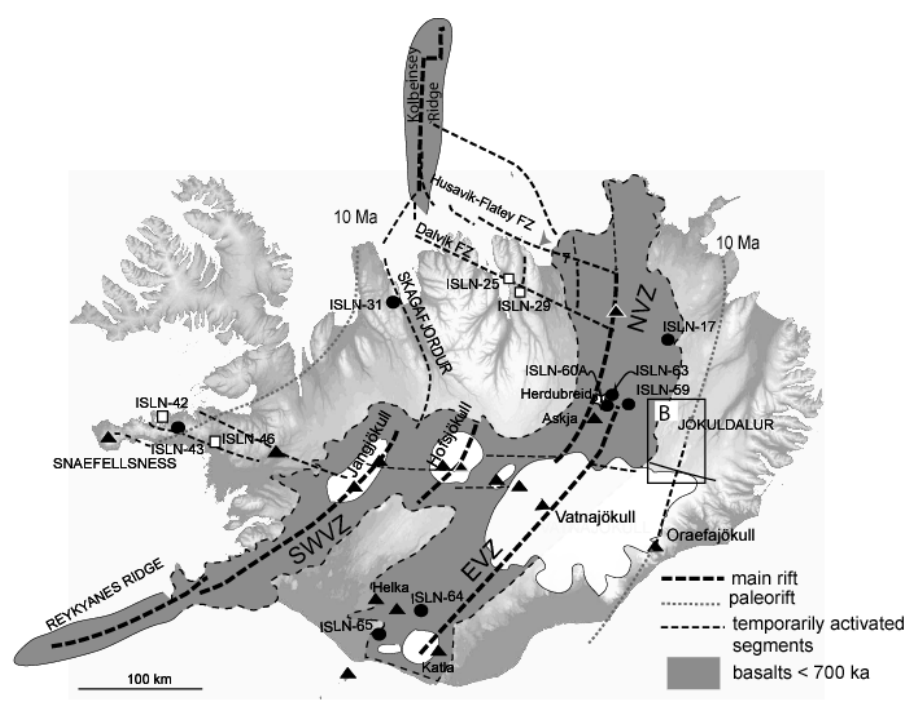

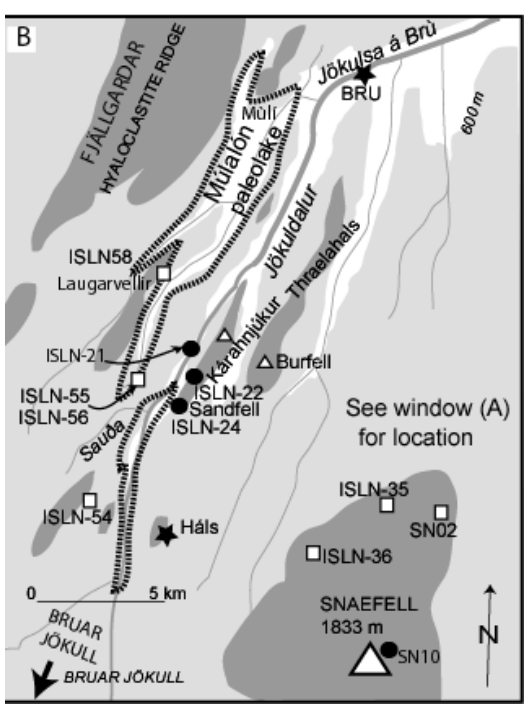

Figure 1 - Location map of the dated samples. a: general map. b: details of the north volcanic zone. Grey stars refer to major volcanic centers. WVZ : west volcanic zone; EVZ: east volcanic zone, NVZ: north volcanic zone, SWZ: southwest volcanic zone. Black dots : Sub-glacial samples. Empty squares : Sub-aerial samples.

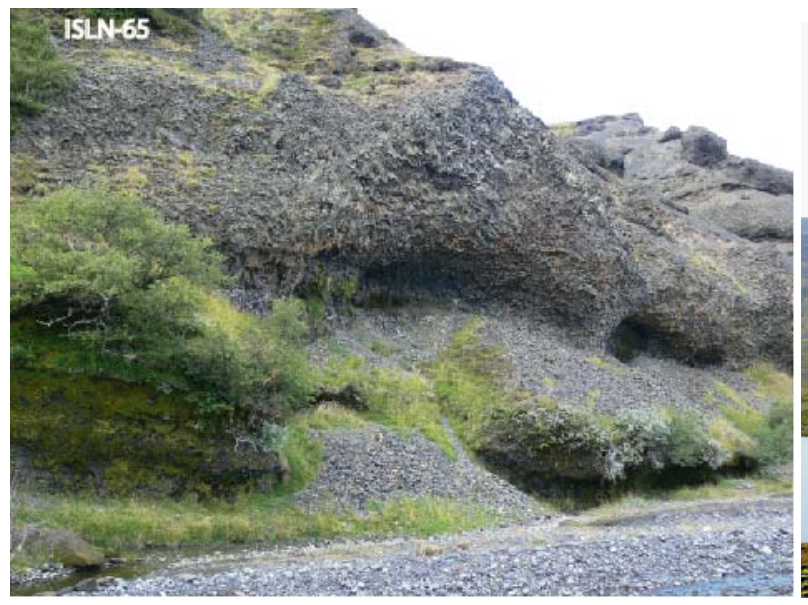

ISLN-43

Figure 2 -Examples of sub-glacial and sub-aerial lavas. ISLN-65, Móberg Pórósfell, details on the cube jointed part of the hyaloclastite unit. ISLN-59, massive rounded block from the Upptyppingar hyaloclastite ridge. ISLN-43, intrusion within the hyaloclastite formation of Móberg Vatnafell. ISLN-46, sub-aerial columnar jointed lava of Gerduberg. ISLN-56, upper part of a partially dismantled sub-aerial lava close to Mülalön.

\section{Results and discussion}

Analytical reproducibility, at the $2 \mathrm{~s}$ level on the ages, is observed for all samples including the very young samples (i.e. ages lower than $150 \mathrm{ka}$ ). The precision is between 10 and $15 \%$ for the two youngest samples (ISLN-17 and ISLN-59). Age precisions of samples dated between 150 and $400 \mathrm{ka}$ with $\mathrm{K}$ contents between 0.5 and $1 \%$ range between 2.5 and $6 \%$. Precision as good as $5 \%$ is obtained 
for $100 \mathrm{ka}$ old samples with $\mathrm{K}$ contents around $1 \%$ (ISLN-46 and ISLN-42). The ages of the sub-glacial samples vary between $1007 \pm 25$ (sample ISLN-31) and $48 \pm 7$ ka (sample ISLN-59). Two samples, ISLN-63 and ISLN-65, respectively from Móberg Herðubreid and Móberg Pórósfell, gave a zero age. Sub-aerial lavas are dated between $759 \pm 27$ (ISLN-58) and $93 \pm 5 \mathrm{ka}$ (ISLN-42).

We can evaluate whether these new ages are good indicators of the crystallisation ages by comparing some of them to previous ${ }^{40} \mathrm{Ar} /{ }^{39} \mathrm{Ar}$ published ages. Two of our samples from the Snaefell volcanic center and two others from the Kárahnjúkar volcanic formation were previously dated by the ${ }^{40} \mathrm{Ar} /{ }^{39} \mathrm{Ar}$ method (Helgason et al., 2003; Helgason et al., 2005). Reported ${ }^{40} \mathrm{Ar} /{ }^{39} \mathrm{Ar}$ ages are consistent with the K-Ar ages, but much less accurate. The K-Ar ages of these samples are not affected by systematic errors due to excess ${ }^{40} \mathrm{Ar}$ and can be regarded as reliable crystallization ages and this validates our experimental procedures.

We can evaluate our new ages by comparing them to the stacked $\mathrm{d}^{18} \mathrm{O}$ record of benthic foraminifera from Lisieki and Raymo (2005). Following the same approach as Licciardi et al. (2007), we plotted the mean ages of the sub-glacial and sub-aerial dated samples combined with the $\mathrm{d}^{18} \mathrm{O}$ proxy record of sea level (Lisieki and Raymo, 2005). This allows a direct comparison of eruption ages with a global paleoclimatic record. Fluctuations of the ice cover in Iceland are representative of the variation in the global ice volume as illustrated by the Lisieki and Raymo record. Nevertheless, at present, $11 \%$ of Iceland is covered in glaciers, so sub-glacial volcanism can occur during interglacials. As a consequence, sub-glacial volcanic products can have radiometric ages corresponding to both glacial and interglacial periods. More probably, sub-aerial volcanics should have radiometric ages coherent with interglacials (warm periods).

In addition, numerous studies about Icelandic volcanism focus on the link between glacial unloading and enhanced volcanism (Maclennan et al., 2002, Sinton et al., 2005, Licciardi et al., 2007).

Our limited dataset combined with the large uncertainties on some of the dated samples and the lack of volume estimates do not allow us to produce a statistical study such as those proposed by Sinton et al. (2005) and Licciardi et al. (2007) but it can be observed that in the studied areas:

1-Six of the sub-glacial samples were emplaced during a warm to cold MIS transition (ISLN-64, ISLN-17, and ISLN-59) or at a cold maxima (ISLN-21, ISLN-24, SN-10). Two of them (ISLN-43, ISLN-22) were emplaced during or briefly after deglaciation.

2- Five of the nine reliably dated sub-aerial lavas (ISLN-58, ISLN-56, ISLN-36, ISLN-25, and ISLN42) were emplaced during a warm to cold MIS transition.

3-Three other sub-aerial lavas were emplaced at the end (ISLN-46) or briefly (SN-02, ISLN-55) after deglaciation.

4-Only one sub-aerial sample (ISLN-29) emplaced at a cold maxima.

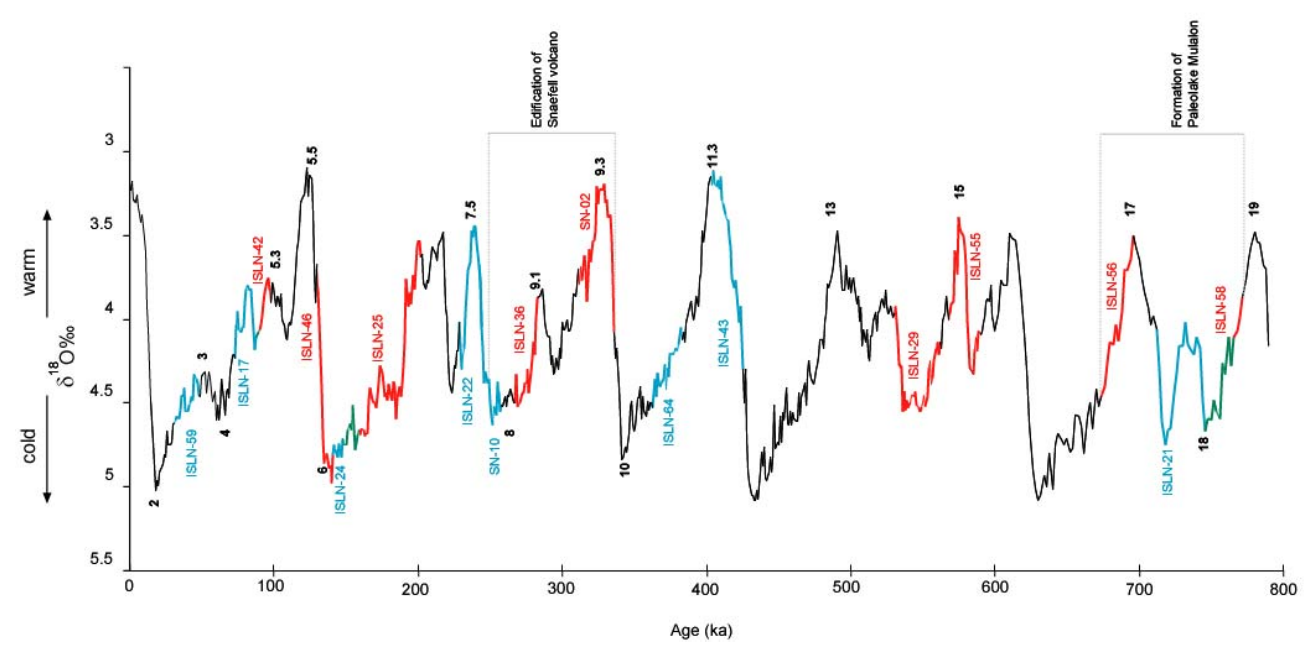

Figure 3 - Representation on the stacked $\delta^{18} \mathrm{O}$ record of benthic foraminifera of the eruption time intervals established from the radiometric ages. In red: sub-aerial eruptions, in blue: sub-glacial eruption, in green: intersection zones between subaerial and sub-glacial ages. In this graphic, ages are reported with an error at two sigma error on the ages except for subaerial samples older than $500 \mathrm{ka}$ which are reported at the one sigma level. The width of the red and blue sectors cover the age uncertainties. 


\section{Conclusions}

We have successfully established the potential of the unspiked $\mathrm{K}-\mathrm{Ar}$ dating method to date Quaternary Icelandic volcanics because direct comparisons between the ${ }^{40} \mathrm{Ar} /{ }^{39} \mathrm{Ar}$ and the unspiked KAr methods demonstrate that recent Quaternary (i.e., younger than $500 \mathrm{ka}$ ) basalts from Iceland can be reliably dated using the K-Ar clock in general and the unspiked K-Ar method in particular. Nevertheless, despite the good accuracies obtained for most of our K-Ar ages, we are not able at this time to establish a clear correlation between climate and volcanism and to demonstrate a clear link between deglaciation and enhanced volcanism. But, based on this promising work, a further step is now the extensive dating of Quaternary Móbergs to check whether we reach the same conclusions as Licciardi et al. (2007), who proposed that most of the recent Móberg edifications coincide or shortly follow important warming events.

\section{References :}

Bourgeois, O., Dauteuil, O., Van Vliet-Lanoë, B., 1998. Pleistocene sub-glacial volcanism in Iceland : tectonic implications. Earth and Planetary Science Letters 164, 165-178.

Einarsson, T., Albertsson, K.J., 1988. The glacial history of Iceland during the past three million years, Philos. Trans. R. Soc. Lond. 318, 637-644.

Flude, S., Burgess, R., McGarvie, D.W., 2008. Silicic volcanism at Ljosufjöll, Iceland : Insights into evolution and eruptive history from Ar-Ar dating. Journal of Volcanology and Geothermal Research 169, 154175.Smellie, J.L., 2000. Sub-glacial eruptions. In: Geirsdttir, A., Hardardottir, J., Eirıksson, J., 1997. The depositional history of the Younger Dryas-Preboreal Budi moraines in southcentral Iceland. Arctic Alpine Research 29, 13-23.

Gudmundsson, A., 1986. Mechanical aspects of postglacial volcanism and tectonics of the Reykjanes peninsula, southwest Iceland. Journal of Geophysical Research 91, 12711-12721.

Helgason, J., Duncan, R.A., 2001. Glacial-interglacial history of the Skaftafell region, southeast Iceland, 0-5 Ma. Geology 29, 179-182.

Helgason, J., Duncan, R.A., 2003. Ar-Ar age dating of the Kárahnjúkar volcanic formation. Ekra Geological Consulting, Report on the Kárahnjúkar Hydroelectric Project made for Landsvirkjun (Iceland power company), August 2003. LV-2003/090, 38 pp.

Hardarson, B.S., Fitton, J.G., 1991. Increased mantle melting beneath Snaefellsjökull volcano during late Pleistocene deglaciation. Nature 353, 62-64.

Hoppe, G., 1982. The extent of the last Iceland ice sheet, Jökull 33, 3-11.

Ingolfsson, O., Björck, S., Haflidason, H., Rundgren, M., 1997. Glacial and climatic events in Iceland reflecting regional North Atlantic shift during the Pleistocene-Holocene transition. Quat. Sci.Rev.16, 1135-1144.

Jull, M., McKenzie, D., 1996. The effect of deglaciation on mantle melting beneath Iceland. Jour. of Geophysical Research 101, 21815-21828.

Licciardi, J.M., Kurz, M.D., Curtice, J.M., 2007. Glacial and volcanic history of Icelandic table mountains from cosmogenic ${ }^{3} \mathrm{He}$ exposure ages. Quaternary Sciences Review 26, 1529-1546.

Lisieki, L.E., Raymo, M.E., 2005. A Pliocene-Pleistocene stack of 57 globally distributed benthic $\mathrm{d}^{18} \mathrm{O}$ records. Paleoceanography 20, doi: 1029/2004PA001071.

Maclennan, J., Jull, M., McKenzie, D., Slater, D., Grönvold, K., 2002. The link between volcanism and deglaciation in Iceland. Geochemistry Geophysics Geosystems 3, 1062, doi :10.129/2001GC000282.

McGarvie, D.W., Burgess, R., Tindle, A.G., Tuffen, H., Stevenson, J.A., 2006. Pleistocene rhyolitic volcanism at the Torfajokull central volcano, Iceland: eruption ages, glaciovolcanism, and geochemical evolution. Jökull $56,57-75$.

McGarvie, D.W., Stevenson, J.A., Burgess, R., Tindle, A.G., 2007. Volcano-ice interactions at Prestahnúkur, Iceland: rhyolite eruption during the last interglacial-glacial transition. Annals of Glaciology, 45 38-47.

Saemundsson, K., 1991. Jardfraedi Kröflukerfisins, in Nattura Mytvatns, edited by A. Gardarsson and A. Einarsson, 24-95, Hid islenska natturufraedifelg, Reykjavik

Sigurdsson, H., (Ed.), Encyclopedia of Volcanoes. Academic Press, San Diego, 403-418.

Sigvaldason, G.E., Annertz, K., Nilsson, M., 1992. Effect of glacier loading/deloading on volcanism: Postglacial volcanic production rate of the Dyngjufjöll area, central Iceland. Bulletin of Volcanology 54, 385-392.

Sinton, J., Grönvold, K., Saemundsson, K., 2005. Postglacial eruptive history of the western volcanic zone, Iceland. Geochemistry Geophysics Geosystems 6, Q12009, doi :10.1029/2005GC001021.

Slater, L., Jull, M., McKenzie, D., Grönvold, K., 1998. Deglaciation effects on mantle melting under Iceland: Results from the northern volcanic zone. Earth and Planetary Science Letters 164, 151-154.

Werner, R., Schminke, H-U., 1999. Englacial vs lacustrine origin of volcanic table mountains: evidence from Iceland. Bulletin of Volcanology 60, 335-354. 